\title{
The 2001-3 electricity distribution price control review in the Netherlands: regulatory process and consumer welfare
}

\author{
Paul H. L. Nillesen • Michael G. Pollitt
}

Published online: 24 February 2007

(C) Springer Science+Business Media, LLC 2007

\begin{abstract}
The outcome of the first electricity distribution price control review in The Netherlands did not deliver the savings initially suggested by the regulator (DTe). During the course of the first 3-year regulatory period, DTe revised the X-Factors four times. The impact on tariffs has been substantial. DTe initially announced in 2000 that savings would be equivalent to $25 \%$ of electric distribution revenues ( $€ 2$ bn). However, final X-Factors in May 2003 resulted in savings of $10 \%$ of revenues. The total cost to consumers - when compared to the most probable outcome - has been $€ 140 \mathrm{mln}$ ( $7 \%$ of total revenues).
\end{abstract}

Keywords Regulation · Benchmarking - Consumer welfare · Regulatory process $\cdot \mathrm{X}$-Factor

JEL Classifications D42 $\cdot$ D60 $\cdot$ K2 $\cdot$ L5

\section{Introduction}

The price control review has become a key element of independent economic regulation of network utilities around the world in recent years. Once every

\footnotetext{
P. H. L. Nillesen ( $\varangle)$

PricewaterhouseCoopers Advisory,

De Entree 201,Amsterdam,

The Netherlands

e-mail: Paul.nillesen@nl.pwc.com

M. G. Pollitt

Judge Business School, Cambridge CB2 1AG, UK

e-mail: m.pollitt@jbs.cam.ac.uk
} 
3-5 years the regulatory agency responsible for setting prices for monopoly network companies in telecoms, electricity, gas, water, railways or airports deliberates on what the maximum prices for these services should be, and sets them for the upcoming control period.

Many countries around the world now have electricity price control reviews in the wake of privatization and deregulation of electricity generation and the gradual opening up to competition of final markets for electricity supply (or retail). Jamasb \& Pollitt (2001), in a survey of 23 OECD and leading developing countries, found that 13 countries had price control periods of 3-5 years. The approach contrasts sharply with the previous regime under public ownership where there was an annual determination of prices, investment programmes, and other objectives, by the relevant government ministry following a more or less formal process of internal consultation between the ministry and the companies it regulated. In the US, Sappington, Pfeifenberger, Hanser, and Basheda (2001) found that at least 16 out of 50 US states had introduced some form of multiyear price control (often amounting to a nominal rate freeze for domestic customers) as opposed to the traditional third party initiated rate review. Multi-year price-caps in the US differ from those in other countries in that they are voluntary agreements between firms and regulators and lack statutory backing.

The Netherlands adopted a price control review approach to economic regulation of its electricity distribution and transmission network companies in 1998 with the Electricity Act. ${ }^{1}$ Originally the first price control period was to be from 1 January 2001 to 31 December 2003. The first consultation document for this price control review period was published in July 1999 (DTe, 1999). However, the process went badly wrong. The Dutch energy regulator (DTe) revised the $\mathrm{X}$-Factors four times during a period of 3 years; these X-Factors fluctuated substantially. Two major court cases before the industrial tribunal $(\mathrm{CBb})$ were lost by the DTe regarding the interpretation of the Electricity Act. The Final $\mathrm{X}$-Factors (and the customer savings) were significantly lower than the initial proposals.

The cost to consumers of this failure to implement price controls as originally envisaged has been substantial. In this paper we present an analysis that attempts to quantify the costs of this regulatory failure. DTe initially announced in 2000 savings of approximately $€ 511 \mathrm{mln}$ for customers $(25 \%$ of annual distribution revenue). However, mistakes in the data, methodology and timetable pressure revealed that this figure was an overestimation. The possible savings calculated in 2002, using actual audited and corrected data, were $€ 384 \mathrm{mln}$ (19\% of annual distribution revenue). When DTe finally set the X-Factors for the first regulatory period in May 2003, the mistakes from the past meant it could only reduce revenues by $€ 209 \mathrm{mln}$ ( $10 \%$ of revenue). Therefore, as a result of this regulatory failure Dutch electricity distribution customers have

1 Ministry of Economic Affairs (2003a), Wet van 2 juli 1998, houdende regels met betrekking tot de productie, het transport en de levering van elektriciteit (Elektriciteitswet 1998) (Stb. 2003, 235), The Hague. 
paid $€ 175 \mathrm{mln}$ more in tariffs than would have been possible over a 3 -year period.

In what follows we seek to document the course of the price review for the period 2001-2003. We provide an analysis of the effects of different stages of the review on customer bills and the consequences for consumer welfare. We conclude by discussing what can be learned from this episode by regulators and legislators around the world.

\section{Benchmarking and incentive regulation}

Outside the US, incentive-based regulation is synonymous with RPI-X (or CPI-X) regulation, as first suggested by Littlechild (1983). Such price cap regulation usually allows average prices (or revenue) to rise by the rate of inflation minus an efficiency factor $(\mathrm{X})$, which reflects the potential for relative productivity improvement in the regulated firm. Under both Performance-based Ratemaking (PBR) and RPI-X companies retain extra profits made under the control formula. ${ }^{2}$ Price-cap regulation decouples profits from costs by setting maximum prices for the duration of a specific period (or regulatory lag).

An important feature of incentive regulation is the use of benchmarking, which can be broadly defined as the comparison of a firm's actual performance against some pre-defined reference or benchmark performance. A perceived advantage of benchmarking has been that it reduces the information asymmetry problem that occurs in rate of return (ROR) regulation by reducing the regulator's reliance on the firm's own costs, but references the price to an external non-influencable benchmark.

The most contentious issue in price-cap regulation is the basis for determining efficiency improvements and the translation of these into tariff changes (X-Factors). Regulators have adopted a variety of benchmarking methods to arrive at X-Factors. The main approaches can be divided into three broad types: (i) pre-reform approaches where the focus is on historically observed costs (US ROR regulation), (ii) conjectures about firm-specific efficiency (CPI-X) as undertaken by European and Australian electricity regulators, and (iii) industry-wide (or wider economy) productivity indices that some reform-oriented Public Utility Commissions (PUC) in the United States are using. ${ }^{3}$ The European regulators have generally adopted firm-specific conjecture-based benchmarking methods as the basis on which to calculate the X-Factors. The PUCs that have adopted PBR have tended to use either historically observed costs (ROR) or industry wide productivity measures such as Total Factor Productivity (TFP) to calculate the efficiency requirements (see Jamasb \& Pollitt, 2001).

2 For the purposes of this study, unless specified, we do not differentiate between a price and a revenue cap regulation based on the CPI-X formula.

3 See also Jamasb \& Pollitt (2001) and Pollitt (1995), Coelli, Rap, and Battese (1998) and DTe (1999). 


\section{Electricity and regulation in The Netherlands}

The Dutch electricity and gas distribution sector is predominantly in public ownership (the exception being two small gas companies owned by Germany's RWE). Following a wave of consolidation during the 1990s, there are now three large vertically integrated energy distribution companies, with a combined market share of $91 \%$. Nuon and Essent are roughly equal with market shares of $33 \%$ (both also have generation assets ${ }^{4}$ ), and Eneco has around 25\% market share following its purchase on the fourth-largest energy company REMU in December 2002. There are approximately 7.3 million customers in The Netherlands. Distribution is vertically separated, from high voltage transmission, with the state-owned company TenneT being responsible for the national transmission system. For the purposes of this paper we focus on these three companies when discussing the events of the first regulatory period. Figure 1 shows the areas where Nuon, Essent, and Eneco currently operate.

\section{The process}

The liberalisation of the Dutch energy sector follows the long and drawn-out process of agreeing the EU Electricity Directive and EU Gas Directive in the middle of 1996 and middle of 1998, respectively. ${ }^{5}$ The Directive for electricity was implemented in The Netherlands with the enactment of the Electricity Act 1998 (or E-Act). ${ }^{6}$ The discussion below draws heavily on the detailed summary of events from a more legal perspective by Janssen \& Pigmans (2004).

The E-Act set-up a regulator and required the integrated energy companies to split their tariffs into a retail and network component. This split was to take effect in 2000 and was to be based on the integrated tariffs of the companies in 1996. The network tariffs were differentiated between the various voltage levels using the "cascade" principle, where consumers pay for all the voltage levels they use. Thus, a residential customer pays for the low voltage grid and part of mid and higher voltage grids, whereas a high voltage customer only pays for the high voltage grid.

The E-Act also requires the regulator to set $\mathrm{X}$-Factors for the companies. The $\mathrm{X}$-Factors are set for a regulatory period, which can vary between 3 and 5 years.

4 Nuon recently completed the purchase of Reliant's UNA assets in December 2003.

5 Directives nr. 96/92/EC and 98/30/EC. In the summer of 2003 two new Directives nr. 2003/54/EC and 2003/55/EC were agreed that altered the original Guidelines and were meant to be implemented before July 2004. Under these Directives all business customers should be free to choose their supplier from 1 July 2004 and all residential customers from 1 July 2007. It also requires legal unbundling for transmission by 1 July 2004 and by 1 July 2007 for distribution. It foresees regulated Third Party Access and requires each country to establish a regulator (Germany has been the exception in the EU - but has recently established a regulatory authority responsible for energy-BundesNetzagentur).

6 Ministry of Economic Affairs (2003a), Wet van 2 juli 1998, houdende regels met betrekking tot de productie, het transport en de levering van elektriciteit (Elektriciteitswet 1998) (Stb. 2003, 235), The Hague. 


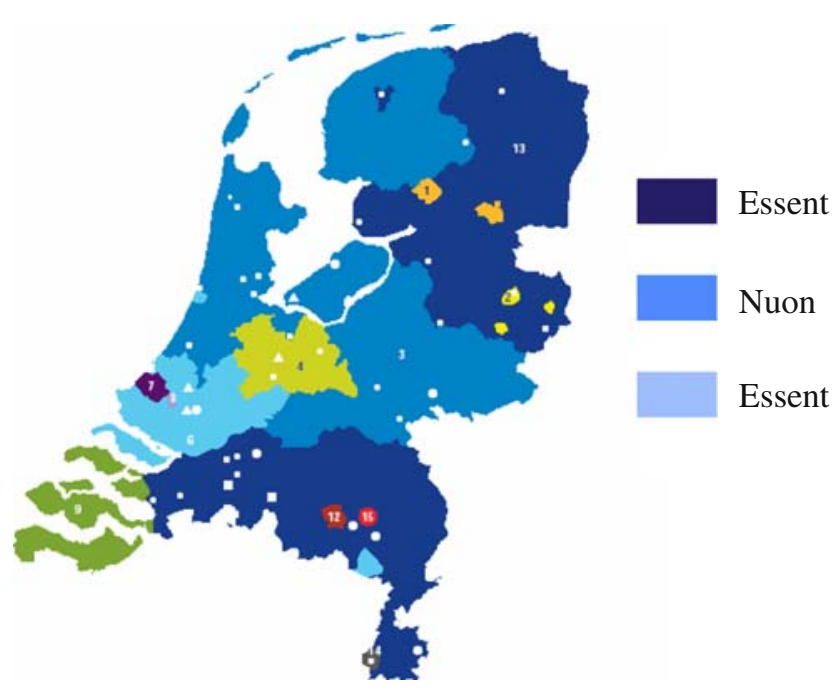

Fig. 1 The areas where Nuon, Essent, and Eneco currently operate. Source: EnergieNed

The formula for adjusting the tariffs is CPI-X (similar to RPI-X). The companies are allowed to adjust their tariffs by CPI, whilst simultaneously adjusting their tariffs with the X-Factor.

On 1 August 1998 the Dienst uitvoering en Toezicht energie (DTe) was set up and became a separate chamber of the Dutch competition authority (the NMa). In July 1999 the DTe published its first consultation document Price Cap Regulation in the Electricity Sector. ${ }^{7}$ The procedure followed by the DTe-and required by law-allowed companies to provide input into the consultation document, after which the DTe published its methodology and subsequently the $\mathrm{X}$-Factor decisions. Relevant parties could then appeal against these decisions to the NMa. If after this appeal, companies were still not satisfied with the outcome they could appeal to a special tribunal for business (College van Beroep voor het bedrijfsleven, $\mathrm{CBb}$ ). A similar process-including X-Factors-was set up for the supply tariffs of the retail companies, as household customers and small businesses were not yet free to choose their supplier.

As well as specifying that the first regulatory period would be for three calendar years (2001-2003) the 1999 consultation document further stated that

"It is the DTe's remit to formulate sensible rules and incentives aimed at enabling the latter category of actors [network operators] to perform fairly, safely and with maximum efficiency as well as monitor the proper implementation of regulations and ascertain whether the incentives are having the appropriate effect." (DTe, 1999, p. 4)

\footnotetext{
7 DTe (1999), Price Cap Regulation in the Electricity Sector, Information and Consultation Document, July 1999, The Hague.
} 
In the 1999 consultation document the DTe sets out its basic principles

(i) Tariffs in 2000 should be based on the tariffs in 1996 (adjusted for volume growth) - also known as the $1996=2000$ basis;

(ii) Output steering (light-handed regulation) and the use of comparative benchmarking - where DTe stated that "the principle of using different methodologies to cross-check each other..." was to be applied; ${ }^{8}$ and

(iii) Regulation to be developed within the context of an internationalisation of the energy sector and the (possible) privatisation of municipal-owned companies.

However, when the Guidelines for Price Cap Regulation of the Dutch Electricity Sector ${ }^{9}$ were published in February 2000, it became clear that the DTe had opted to only use Data Envelopment Analysis (DEA)-a nonparametric linear programming technique-arguing that this technique was the most appropriate given the small sample size and that it was based on actual results, unlike parametric approaches that involved estimations. ${ }^{10}$ In the 1999 consultation document, DTe had discussed parametric techniques, such as Corrected Ordinary Least Squares (COLS) and Stochastic Frontier Analysis (SFA).

The DTe stated that it would use a Constant Returns to Scale (CRS) DEA model arguing that companies were in control of the optimal scale by being able to merge or de-merge. The DEA model had total standardised cost (as opposed to DTe's initial intentions of using only operating costs) as the only input factor and number of customers (small and large), $\mathrm{kWh}$ transmitted, number of transformers, maximum simultaneous demand (distribution and transmission), and network length as output factors. Total standardised costs consist of a depreciation allowance and a return on the Regulated Asset Base (RAB).

The DTe also stated that

“..., it is important to stress that DTe is not proposing to adopt a mechanistic approach to the determination of X-Factors for the companies, based solely on efficiency scores from a benchmarking exercise."(DTe, 2000c, p. 4)

\section{Setting the $X$-Factor}

In order to set the X-Factor, DTe undertook three steps. First, the starting point for the regulatory period was the actual revenue in 2000. Because of the $1996=2000$ principle DTe had a good estimate of the 2000 revenues - although these would only become available later. In order to compare and benchmark the different operators, DTe calculated standardised revenue. This standardised revenue consisted of actual operating and maintenance expenditure (in the first

\footnotetext{
8 DTe (1999), op. cit., p. 24.

9 DTe (2002b), Guidelines for Price Cap Regulation of the Dutch Electricity Sector, February 2000, The Hague.

10 See Coelli, Rap, and Battese (1998) for an introduction to efficiency and productivity analyses.
} 
X-Factor round forecasts were used), a depreciation allowance based on the $\mathrm{RAB}$, and a rate of return using a regulatory weighted average cost of capital. This standardised revenue was then benchmarked against the set of outputs described earlier. The relative efficiency scores from the benchmarking were applied to the standardised revenue to determine the efficient revenue level for each operator. The annual X-Factor was then calculated as the difference between actual revenue in 2000 and the target efficient standardised revenue at the end of the regulatory period evenly spread out over the 3-year period.

In order to compare the outcomes of the various X-Factors we calculate the cumulative change in allowed revenues-discounted by the regulated return $(6.6 \%)-$ for the 3-year period. These savings are compared to the actual 2000 revenue of the companies. This allows an easy comparison of the impact of the various X-Factors. The actual X-Factors - as published-by DTe cannot easily be compared because they refer to different revenue bases. As the components that made up the "revenue base" in the benchmarking changed, the subsequent published X-Factors change. For example, certain costs were considered uncontrollable and therefore excluded from the revenue base. This has an artifical impact on the published X-Factors. By re-scaling everything back to the starting revenue we can compare the total revenue reductions. At each stage of the process we report the actual X-Factors - as published by DTe-and the effective cumulative X-Factor based on the revenue reduction over the 2000 starting revenue. Because Nuon, Essent, and Eneco consist of many smaller network operators we also re-calculate the effective X-Factor for the groups as a whole.

In Table 1 we report: the company (column 1), the number of customers (column 2), and the actual starting revenue in 2000 (column 3). The starting revenue in 2000 is not known for the subsidiaries of Eneco, Essent, and Nuon. In order to examine the impact of cost reductions on the subsidiary companies we calculate a proxy for the starting revenue (column 3) by taking the ratio of the revenue base used by DTe for the calculations (column 4) to the total revenue base and multiplying this by the actual starting revenue in 2000 for the group (these figures are denoted in italic and bold). The X-Factors as reported by DTe are reported in column 5. The cumulative discounted revenue reduction per company is reported in column 6 and calculated by taking the absolute difference in revenue reductions as reported by DTe. The revenue reduction is discounted using the DTe's weighted average cost of capital-6.6\%. The cumulative savings per customer are reported in column 7 . The percentages reported in column 8 compare the total revenue reduction (column 6) to the starting revenue in 2000 (column 3).

\subsection{X-Factor 2000: the initial errors}

Table 1 reports the results from the first X-Factor set in September 2000 by DTe (and to be implemented from 2001). The table shows substantial revenue reductions for all the companies, with the exception of Delta and one of the Essent companies (Essent Brabant). Nuon consists of three subsidiaries but was counted as one company in the $2000 \mathrm{X}$-Factors. Total cumulative revenue 


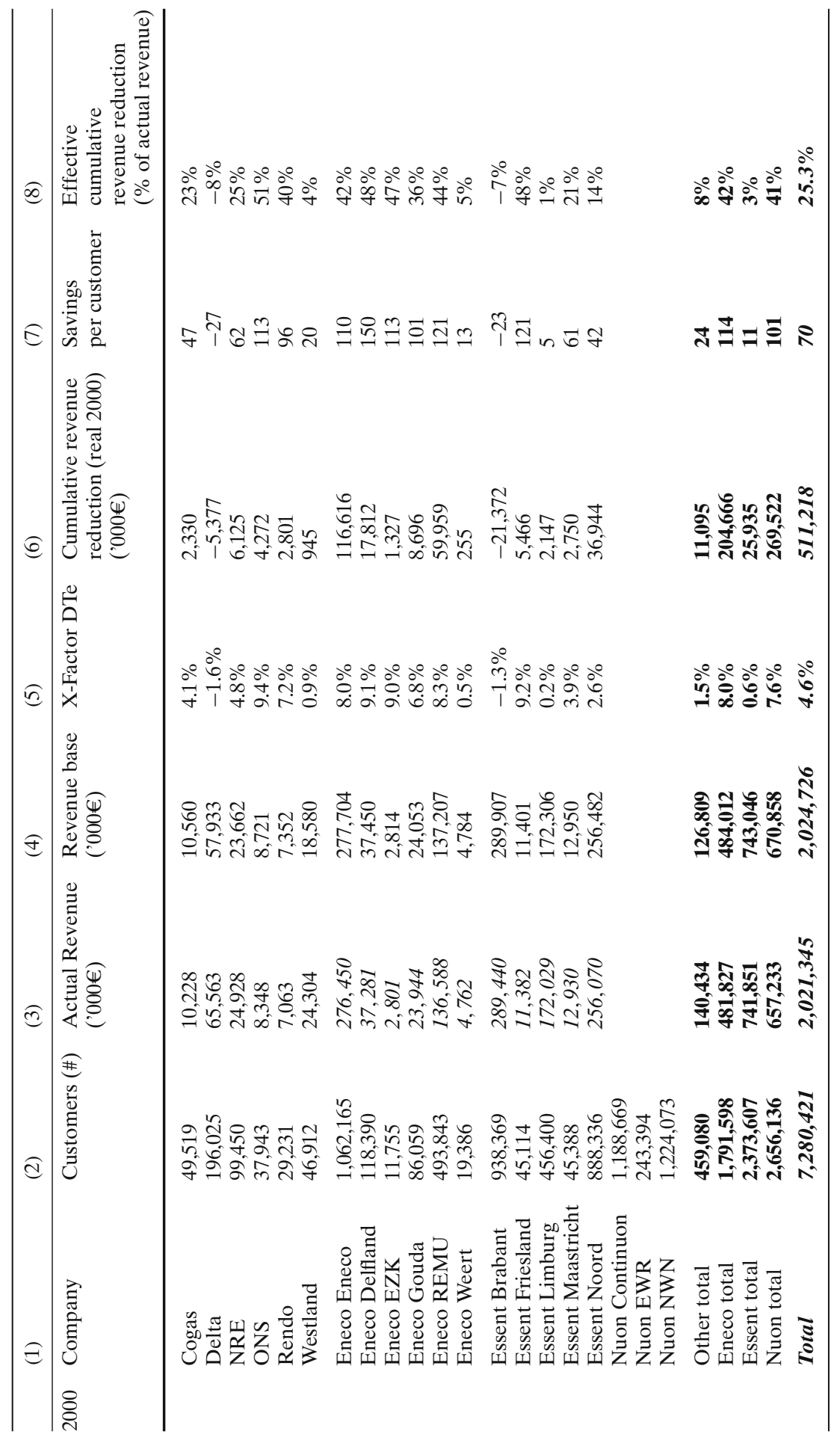


reductions for the sector were $€ 511 \mathrm{mln}$ or $€ 70$ per customer. This is equivalent to $25 \%$ of revenue in 2000 of $€ 2 \mathrm{bn} .{ }^{11}$ Delta's customers face a tariff increase of $€ 27$ per customer, whereas Eneco Delfland customers receive a tariff reduction of $€ 150$. Remarkable is the stark difference between the X-Factors for Essent, Nuon and Eneco. Whereas Eneco and Nuon both faced substantial reductions in their revenues ( 42 and $41 \%$, respectively), Essent only faced a minor reduction in revenues $(3.5 \%)$. The fact that Essent Brabant (largest by revenue of the Essent Group) received an X-Factor of $-1.3 \%$ pulls down the total revenue reductions required for the Essent group.

There was substantial criticism of the DTe's results and most companies (except notably Essent) subsequently appealed to the NMa. ${ }^{12}$ The appeal to the NMa is the intermediary step before appealing to the special tribunal for business - the CBb. During the NMa appeal process the $2000 \mathrm{X}$-Factors were implemented by the companies. Part of the appeal procedure was a natural reaction by the companies to the fact that this was the first distribution price control review. Given the fact that there was no prior jurisprudence regarding the distribution price control review, most parties felt that testing the legal boundaries of the DTe was necessary. The appeal procedure was also a way to ensure that the companies remained a stakeholder in the process.

The content of these appeals focused predominantly on the allegation that DTe did not cross-check the relative efficiency scores from the benchmarking for consistency, as it had earlier stated in the consultation document. The benchmarking - according to the companies - did not fairly reflect the relative positions of the companies. As part of their critique, companies submitted alternative efficiency analyses that demonstrated different positions. The comments focused on both model specification (see Nillesen \& Telling, 2001) and benchmarking methodology. The analysis by Nillesen \& Telling (2001) using the same data but a different model specification (network length as input instead of as output) resulted in completely different results.

Exactly a year later (September 2001) the NMa announced its decision on the appeal (2001 X-Factors). In this decision the NMa discussed the issues raised by the companies and in the same document set out a revised approach (as DTe executed and was closely involved in assessing the appeal, we refer to DTe). Firstly, as a result of the appeal procedure the DTe adopted a different approach to calculating the value of regulated assets. Initially, the DTe had discounted the regulated profits to calculate the RAB. ${ }^{13}$ This method was now replaced by

11 In the DTe's press release announcing the X-Factors (26 September 2000) it refers to an average X-Factor of $5.9 \%$ for the sector, which results in a total revenue reduction of $€ 590 \mathrm{mln}$. However, it subsequently had to make some adjustments as it erroneously forgot some data from the smaller companies. In addition, the DTe did not discount the cumulative savings, therefore the final discounted savings are $€ 511 \mathrm{mln}$.

12 See for example, KPMG BEA (2000), Nillesen \& Telling (2001), and NYFER (2001).

13 As tariffs were fixed at the $1996=2000$ level, all that was required to calculate the RAB was to subtract operational expenditures and depreciation charges. The remainder were the regulated profits, which when discounted by the DTe's weighted average cost of capital would give the RAB value. 
using the companies' actual historical investments and depreciating these using standardised depreciation schedules. Secondly, DTe updated the benchmarking data set by removing certain mistakes and data errors. NMa claimed that the model specification was methodologically superior and that Data Envelopment Analysis (DEA) was the only appropriate benchmarking technique given the limited sample size. Importantly, DTe applied the legal principle of no "reformatio in peius", stating that

"By virtue of section 7:11, clause 1, of the General Administrative Law Act, the director of the DTe is also of the opinion that the party lodging a notice of objection must not, as a result, be put in a worse position than if he had not made an objection (principle that 'reformatio in peius' is forbidden). Therefore for a grid operator no more unfavourable $\mathrm{X}$ must be set than had been set in relation to the primary decision, even if this stems from application of the amended regulatory methodology." DTe (2001) p. $36 / 37$

"Furthermore, in the opinion of the director of the DTe the relevant principle (no 'reformatio in peius') applies only with respect to the X-factor as the end result of applying the regulatory method, not with respect to any interim result on the basis of a step in the method (in that case more favourable interim results for a grid operator may be passed on, but not more unfavourable ones). In the final analysis, when the decision is made on the objection a grid operator must not be put in a worse position than if the grid operator had not made an objection." DTe (2001) p. 36/37

The text suggests DTe was forced to implement this principle, referring to section 7:11, clause 1, of the General Administrative Law Act. The article DTe refers to states: "If the objection is admissible, the disputed order shall be reviewed on the basis thereof". ${ }^{14}$ From this alone it is not clear whether the no reformation doctrine - as applied by DTe-was legally necessary. There is no further evidence that discusses this issue at that moment. The introduction of no reformatio in peius essentially introduced a zero-loss incentive for the energy companies. Appealing decisions could only benefit the companies.

\subsection{X-Factor 2001: introducing the zero-loss effect}

Table 2 reports the $\mathrm{X}$-Factors following the appeal by the distribution companies. The results for Essent do not change, as they did not appeal the previous $\mathrm{X}$-Factor decision in 2000. The total revenue reductions for the sector decreased from $€ 511 \mathrm{mln}$ to $€ 376 \mathrm{mln}(26 \%)$. The required revenue reduction for the sector drops from 25 to $19 \%$. The average X-Factor set by DTe is the same in 2001 as in 2000. The fall in required revenue reduction is explained by the decrease in revenue base over which the X-Factor is calculated. In 2000 this was circa $€ 2$ bn, whereas in 2001 it was circa $€ 1.8$ bn, as certain costs were labeled non-controllable and excluded from the benchmarking exercise.

14 Algemene Wet Bestuursrecht (Awb). Available at www.justitie.nl 


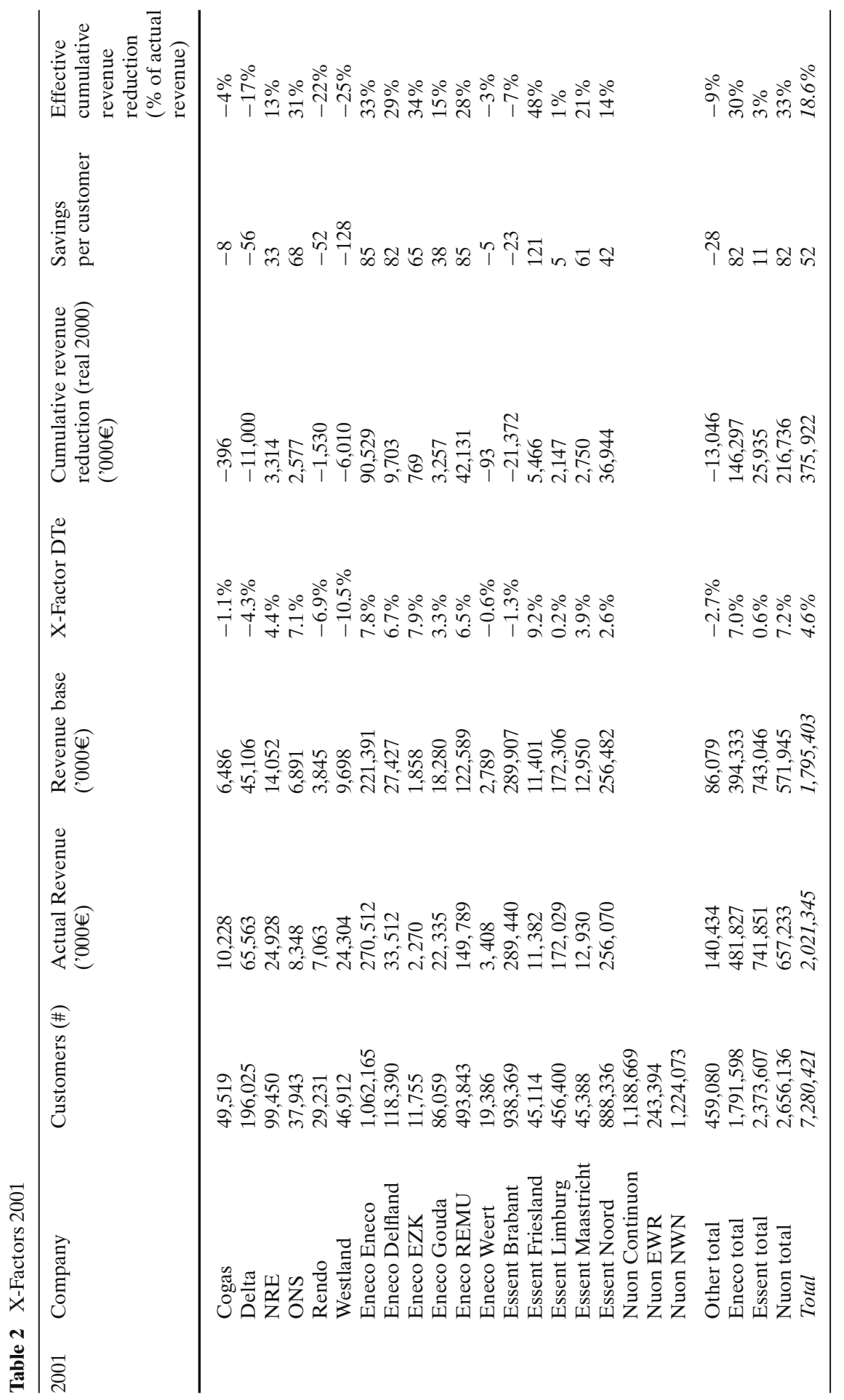


There are some large shifts in the outcomes. In 2000 Rendo and Westland were both required to reduce their revenues by 40 and $4 \%$, respectively. However, in the $2001 \mathrm{X}$-Factors, Rendo and Westland were allowed to increase their revenues with 22 and $25 \%$, respectively. Instead of Rendo's customers receiving a $€ 96$ reduction, they were now faced with a $€ 52$ tariff increase. For Westland there was initially a tariff decrease equivalent to $€ 20$ per customer, whereas in the 2001 appeal decisions customers would face tariff increases equivalent to $€ 128$ per customer.

As a result of the appeal Eneco and Nuon both saw their required revenue reduction decrease from approximately 40 to approximately $30 \%$. For Eneco this was equivalent to $€ 58 \mathrm{mln}$ and for Nuon equivalent to $€ 53 \mathrm{mln}$ in reduced revenue reductions. The results for Essent do not change because they did not appeal the $2000 \mathrm{X}$-Factor decision.

The companies however were still unhappy with the results. The benchmarking exercise and its mechanistic application of the results were a focal point of their criticisms. The final resort for the companies was to take their case to the special business tribunal (the $\mathrm{CBb}$ ). All the companies subsequently lodged their appeals with the court. During this whole process the X-Factors set in 2000 still applied.

At the same time that the discussions surrounding the X-Factors for network operators were taking place, there were discussions about the X-Factors for retail tariffs. The articles describing the methodology for setting the retail tariff X-Factor are exactly the same as for network tariffs. As the retail $\mathrm{X}$-Factors were less data-intensive (and therefore less time-intensive) the appeal procedure had run ahead of the X-Factors for networks. One of the retail companies (Rendo) had already lodged an appeal against its retail tariffs with the $\mathrm{CBb}$. On 6 February 2002 the $\mathrm{CBb}$ ruled that DTe had not acted according to the E-Act's intentions. ${ }^{15}$ According to the $\mathrm{CBb}$ the E-Act did not allow DTe to set X-Factors that could vary between individual companies. Instead the X-Factor had to be uniform for the sector. In Article 58:1:b the E-Act states that

$$
\begin{aligned}
& \text { " } x_{\mathrm{t}}=\underline{\text { the }} \text { discount factor to stimulate the efficient operation by retail } \\
& \text { license holders,...."16 }
\end{aligned}
$$

This was a substantial blow for the DTe and the ruling was unexpected by the sector. ${ }^{17}$ The sector and DTe had until this point not questioned whether a distinction needed to be made between individual or uniform X-Factors. Earlier objections by the companies did not refer to this issue. This was presumably not the intention of the original E-Act as it was also based on experiences in other

\footnotetext{
15 College van Beroep voor het bedrijfsleven (2002a), No AWB 01/623.

16 The original Dutch Article states: " $x_{\mathrm{t}}=$ de korting ter bevordering van de doelmatige bedrijfsvoering door vergunninghouders voor zover het betreft de inkoop van elektriciteit en de diensten met betrekking tot de levering van elektriciteit."

17 See for example Knops (2002), De Pree (2002), De Telegraaf (2002), and Het Financiele Dagblad (2002).
} 
countries with X-Factors systems, and could partly be blamed on poor drafting, but also on a very narrow interpretation by the court.

The DTe announced that same month (February 2002) that it was starting a project called "Correctie Besluiten" (corrected decisions) for the network operators. It intended to issue a new request for information from the network companies, allowing them to revise and update data (some data had been estimated as actual figures had not been available at the time of the 2000 and 2001 $\mathrm{X}$-Factor revisions). This dataset would be then be verified by the companies, before it would be used to re-calculate the X-Factors for the period for a third time. Both DTe and companies took part in this exercise, attempting to agree on a final dataset.

During the intermittent period of regulatory uncertainty following the CBb's decision, the DTe published An Overview of the First Regulatory Review of the Regional Electricity Networks Business in July 2002. ${ }^{18}$ The report contained a detailed discussion of the role of the regulator and the objectives of DTe. In the introduction the DTe stated

"In particular DTe is keen to demonstrate that each of the decisions it has taken during the first regulatory review has been guided by a common set of underlying principles." (DTe, 2002, p. 1)

In addition the DTe stated that it “...it would prefer to provide incentives for the companies to focus their attention on delivering the best services to customers, rather than debating their costs with the regulator." ${ }^{19}$ Importantly, the DTe explains why it had chosen the DEA benchmarking technique over the other possible methodologies

"Regression analysis seeks to explain differences in cost on the basis of a range of factors. In contrast, DEA evaluates whether observed costs can be regarded as reasonable on the basis of the basket of outputs delivered, where the regulator selects which outputs are considered valuable. For this reason alone DTe regards DEA as better suited for use in a regulatory context." (DTe, 2002, p. 27)

As will become clear from the next section, the arguments for or against particular model specifications or methods (such as DEA), were never evaluated by the courts.

\subsection{X-Factor 2002: getting the data right}

In August 2002 DTe published new X-Factors. These new X-Factors were based on the project Correctie Besluiten. Table 3 summarizes the 2002 X-Factors and total cumulative savings for consumers, it does not include the no "reformatio

18 DTe (2002c), An Overview of the First Regulatory Review of the Regional Electricity Networks Business, July 2002, The Hague.

19 DTe (2002c), op. cit. p. 3. 


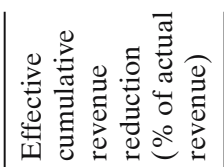

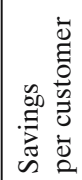

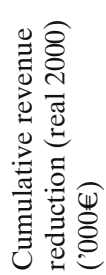

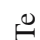

胥

苛

崖

.

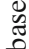

屏

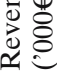

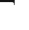

$\stackrel{0}{\Xi}$

จ

$\cong$

胥出

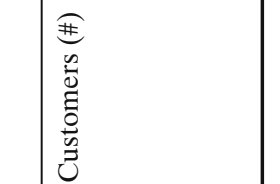

范

Springer

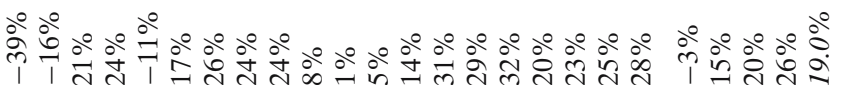

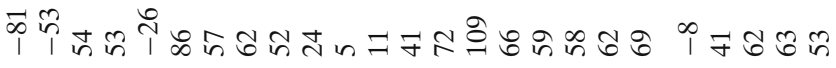

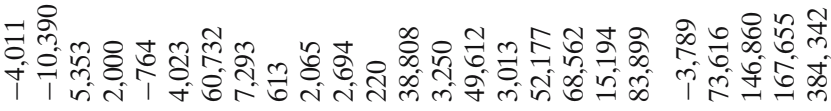

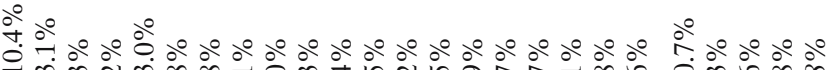

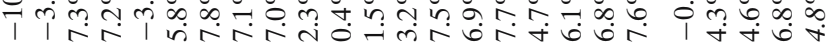

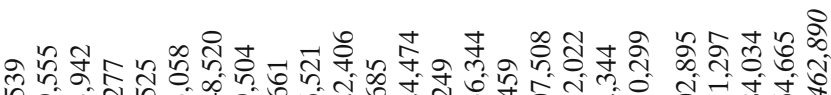

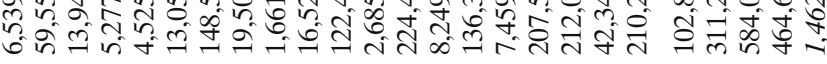

సै

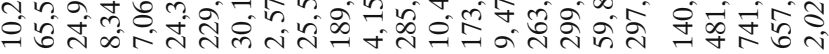

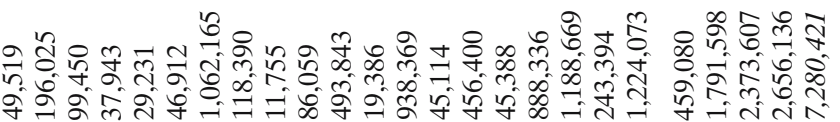

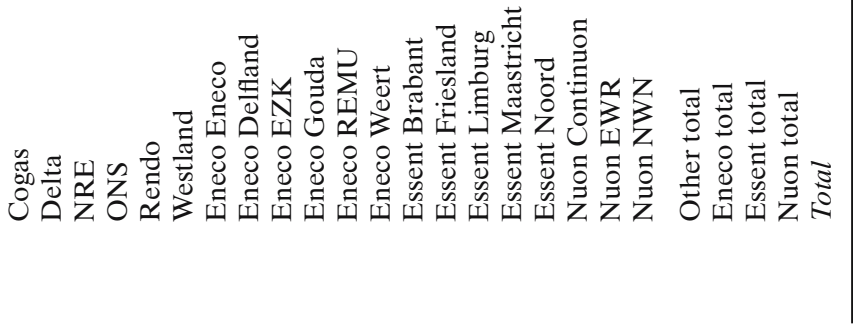


in peius" for Essent. DTe argued that the X-Factor decisions from the Correctie Besluiten were not decisions made based on an appeal, but were completely new decisions, therefore the no reformatio principle did not apply.

Table 3 shows the X-Factors using the "corrected" data and actual 2000 figures for all the companies. The data used in the 2000 and $2001 \mathrm{X}$-Factors was based on estimates and projections of 2000, rather than actual audited data. It excludes the no reformatio in peius - giving a clean picture of the revenue reductions using actual audited 2000 data. The revenue reduction for the sector is similar to the $2001 \mathrm{X}$-Factors decisions. The X-Factors also look similar, but the revenue base over which they are calculated has decreased from circa $€ 2$ bn in 2000 to $€ 1.5$ bn in 2002 . The cumulative reduction in revenue is $19 \%$ of total revenue, with per customer savings of $€ 53$. Given the methodology and approach used by DTe, these results probably best represent the underlying relative positions of the various companies. The use of actual audited data perhaps also allowed a more considered view of the methodology and approach used by DTe.

Judged against the initial X-Factors in 2000, DTe had earlier overestimated the scope for revenue reductions for the sector (and customers) by $33 \%$. In addition, the DTe overestimated revenue reductions for certain companies, whilst underestimating them for others.

Comparing the 2001 and $2002 \mathrm{X}$-Factors, the required revenue reduction drops from $€ 146$ to $€ 74 \mathrm{mln}$ for Eneco and from $€ 217$ to $€ 168 \mathrm{mln}$ for Nuon. Eneco Eneco and Eneco REMU are largely responsible for Eneco's $€ 72 \mathrm{mln}$ decrease. The required revenue reduction for Essent is $€ 147 \mathrm{mln}$. This is substantially more than $€ 26 \mathrm{mln}$ as initially estimated by DTe. Rather than allowing Essent Brabant to increase revenues by $€ 21 \mathrm{mln}$, the 2002 calculations show that there should be a $€ 39 \mathrm{mln}$ revenue reduction. This is a difference of $€ 60 \mathrm{mln}$ (20\% of Essent Brabant's revenue).

The 2002 Correctie Besluiten demonstrates that quality of data is critical in the X-Factor process. DTe should have waited for this "finalized" dataset before publishing X-Factors. It can be argued that the DTe elicited the correct information by publishing X-Factors based on projections and estimates. However, DTe could have obtained the same result by publishing public consultation documents containing the results, and delaying the formal decision-making process, which in the Dutch case meant that mistakes would filter through into later revisions based on new audited (and more accurate) data.

However, the 2002 results were never implemented as there remained uncertainty over the legal basis of individual X-Factors. The uncertainty over individual versus uniform X-Factors (and the legal basis for DTe's approach) was finally removed on 13 November 2002 when the $\mathrm{CBb}$ ruled that the relevant article of the E-Act for setting X-Factors for network operators was to be read in the same way as the article for retail tariffs. ${ }^{20}$

20 College van Beroep voor het bedrijfsleven (2002b), No AWB 01/841, 01/847-53, 01/955, 01/956. This did not come as a surprise to either the sector or DTe. In actual fact DTe had been preparing for this eventuality during 2002. This is confirmed by the consultation note discussing possible solutions published 16 January 2003 by DTe (DTe 2002b). 

" $x_{\mathrm{t}}=$ the discount factor to stimulate the efficient operation by grid oper-
ators"

This meant that according to the E-Act DTe only had the legal basis to set a uniform X-Factor for the sector and not individually varying X-Factors. ${ }^{22}$

\subsection{X-Factor 2003: striking a deal}

After the court decision DTe was forced to reconsider the methodology for setting the X-Factors. In addition, there was a need to get out of the mess and achieve a break-through in the X-Factor discussion.

On 2 December 2002 the DTe announced that the then head of DTe would be replaced. ${ }^{23}$ On 13 December 2002 DTe announced that Gert Zijl would become head of the DTe per 1 January 2003. Mr Zijl had until then been CEO of the national transmission system operator (TenneT). ${ }^{24}$

The new Director's approach to the deadlock was two-fold. First, in January 2003 DTe published a consultation note setting out DTe's proposed approach to repairing the X-Factors. ${ }^{25}$ In this document DTe suggested a tariff benchmark, which would look at actual tariffs rather than at costs and outputs-from which tariffs would be derived. As a second alternative, DTe suggested a standardized tariff benchmark - taking into account different weights of different customer categories. In the document DTe does not discuss the possibility of one-off tariff reductions ( $\mathrm{P} 0$ reductions), which would allow uniform X-Factors to be set. The E-Act does not mention this possibility. Second, DTe initiated behind-the-scenes negotiations with Eneco, Essent, and Nuon.

After months of negotiating and discussing alternative models, a deal was finally presented to all the network operators and signed on 26 May $2003 .{ }^{26}$ The deal covers two regulatory periods, the first from 2001 until 2003 and the second period from 2004 until 2006. As the final deal would be reached in the final year of the first period, it was agreed that the second period would be included. The DTe published the results and followed the public consultation process. All the companies and their shareholders were required to sign the deal and state that they would not appeal during this consultation period and subject to the results of the deal being implemented, would withdraw any remaining appeals

21 The original Dutch Article states: " $x_{\mathrm{t}}=$ de korting ter bevordering van de doelmatige bedrijfsvoering door netbeheerders."

22 One of the unfortunate side-effects of the $\mathrm{CBb}$ rulings was that the actual X-Factor methodology and underlying benchmarking was never tested in a court. Thus, in a sense the legal basis for DTe's approach to setting the X-Factors, has never been verified.

23 DTe (2002d), Directeur De Jong stapt over naar Europees platform energietoezichthouders, press release, 2 December 2002, The Hague.

24 DTe (2002e), Gert Zijl nieuwe directeur DTe, press release, 13 December 2002, The Hague.

25 DTe (2003b), Consultatienotitie: Reparatie X-Factor Netbeheerders Elektriciteit, Visie DTe, The Hague, 16 January 2003.

26 A similar deal was signed in November 2003 with the gas network operators after several months of intense discussions. 
against DTe. For the first regulatory period there was a uniform X-Factor of $3.2 \%$ over total revenue (and thus tariffs), as legally required according to the original E-Act. For the second regulatory period however there are individual $\mathrm{X}$-Factors. These individual X-Factors were set so that all companies converge to the efficient level by 31 December 2006, thus achieving a major target of DTe. The amendments to the E-Act - to allow for this-were not yet in place at the time of the deal.

During these negotiations the Minister for Economic Affairs prepared emergency legislation to repair the uniform versus individual X-Factor text in the current E-Act. A first draft of this legislation was first published on 10 April 2003 (Overgangswet Elektriciteitsproductiesector ${ }^{27}$ ). This repair would allow the DTe to set individual X-Factors and importantly also do this retrospectively (and backdate the X-Factors), allowing DTe to effectively re-take its decisions and ignore the $\mathrm{CBb}$ ruling. The final bill was enacted on 19 August 2003, only after-among other things - the Minister promised the Upper Chamber not to make use of the retrospectivity of the Act. In the final version, the amended E-Act states in Article 41a:1:a

"With regard to the proposal, as mentioned in Article 41:b, the director of DTe sets for each individual grid operator, for a period of 3-5 years, the following

a. the discount factor to stimulate efficient operation..."28

Note that the Act clearly states that "the discount factor" is set for "each individual grid operator".

In the new methodology, the performance of each company is compared to the total weighted output factor that incorporates all different tariff levels and types of customer. For example, it weights low voltage customers differently than high voltage customers. This allows each company to have a "uniform" bill for the services it provides. This is then benchmarked against the standardized costs of the company; the company that provides most value-for-money is set as the reference company. In essence the method is a weighted tariff benchmark against the sector average tariffs. This methodology takes into account all the different types of customers (rather than only small and large customers in the DEA) and the actual tariffs for the services provided. The major drawback of this approach is that it focuses on average performance rather than best-practice performance.

In Table 4 the X-Factors and revenue reductions that were reported in the deal in 2003 are shown. In the 2003 deal all the subsidiaries are merged into the

\footnotetext{
27 The abbreviation for this Act, which repairs a substantial amount of previous legislation, is ironically "Oeps"!

28 The original dutch Article states: "Ten behoeve van het voorstel, bedoeld in artikel 41b, stelt de directeur van de dienst voor iedere netbeheerder afzonderlijk voor een periode van ten minste drie en ten hoogste vijf jaar vast:

a. de korting ter bevordering van de doelmatige bedrijfsvoering."
} 


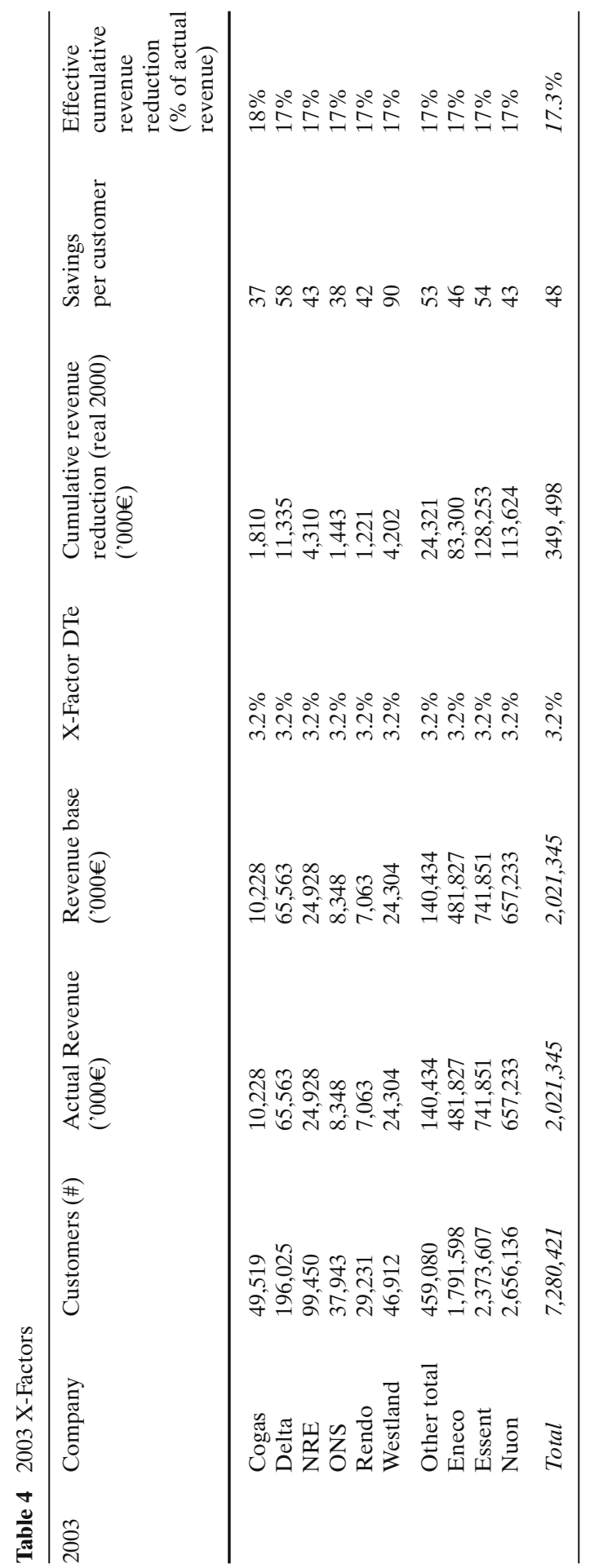


holding company - with one X-Factor set across the whole company. The total revenue reduction for the sector is $€ 349 \mathrm{mln}$ or $17 \%$ of the actual revenue. The individual X-Factors are all set equal at 3.2\% -in line with the requirements of the E-Act. Although the deal is substantially less than the initial X-Factor in 2000 (33\% compared to 2000), it does not differ substantially from the X-Factors in $2002-$ where the most accurate data was used. The difference between the 2002 and 2003 results is only $€ 35 \mathrm{mln}$ (10\% decrease). However, there are some substantial shifts between the companies.

The required revenue reduction from the 2003 deal for Eneco is $€ 10 \mathrm{mln}$ higher than the 2002 calculations. Nuon's revenue reduction is $€ 54 \mathrm{mln}$ lower than calculated by DTe in 2002. Essent's revenue reduction is lower than in the 2002 calculations, but still substantially above the 2000 and 2001 revisions. Delta's revenue increase of $€ 10 \mathrm{mln}$ changes into a revenue reduction of $€ 11 \mathrm{mln}$. NRE, ONS, Essent and Nuon gained $€ 74 \mathrm{mln}$ moving from 2002 to 2003. Cogas, Delta, Rendo and Westland had total revenue reductions of $€ 39 \mathrm{mln}$.

\subsection{Final X-Factor 2003: chains from the past}

However, DTe promised to apply the no reformatio in peius principle in the deal. This was necessary to reach agreement with the sector, as some companies had profited from lower X-Factors. DTe had also introduced this concept in the first place. In practice this meant that if companies were still owed money they were allowed to recover this through their tariffs, whereas those that had earned too much were not required to reimburse customers. ${ }^{29}$ Though the total sector revenue reduction is not dissimilar from the $2002 \mathrm{X}$-Factor result, the impact of no reformatio in peius was substantial-but it was not reported in the deal documentation. We therefore adjust Table 4 by reporting the revenue stream that is most beneficial to the companies-comparing the 2003 outcome with the $2001 \mathrm{X}$-Factors (these were the last official X-factors as the 2002 results were never implemented). If the total required revenue reductions were greater in 2003 than in 2001, we present the 2001 revenue reduction. This way we factor in the no reformatio.

In Table 5 the X-Factors and revenue reductions that were set as a result of the deal in 2003-including no reformatio in peius - are shown. The total revenue reduction for the sector is $€ 209 \mathrm{mln}$ or $10 \%$ of the actual revenue. Essent benefits most from the initial errors that were made in 2000/1.

It can be seen that the adjustment for no reformatio in peius leads to a substantial decrease in revenue reductions, from $€ 349 \mathrm{mln}$ to $€ 209 \mathrm{mln}(67 \%$ reduction). In absolute terms Essent benefits most from the ruling. Instead of seeing its revenue decrease by $€ 128 \mathrm{mln}$ ( $17 \%$ of actual revenue), it is only required to reduce it by $€ 26 \mathrm{mln}$ ( $3 \%$ of actual revenue). The total cost of the no reformatio in peius is $€ 140 \mathrm{mln}$ of which $€ 102 \mathrm{mln}$ is directly attributable to

29 However, from 1 January 2004 all companies will start from the adjusted starting point taking the full 3.2\% X-Factor into consideration. 


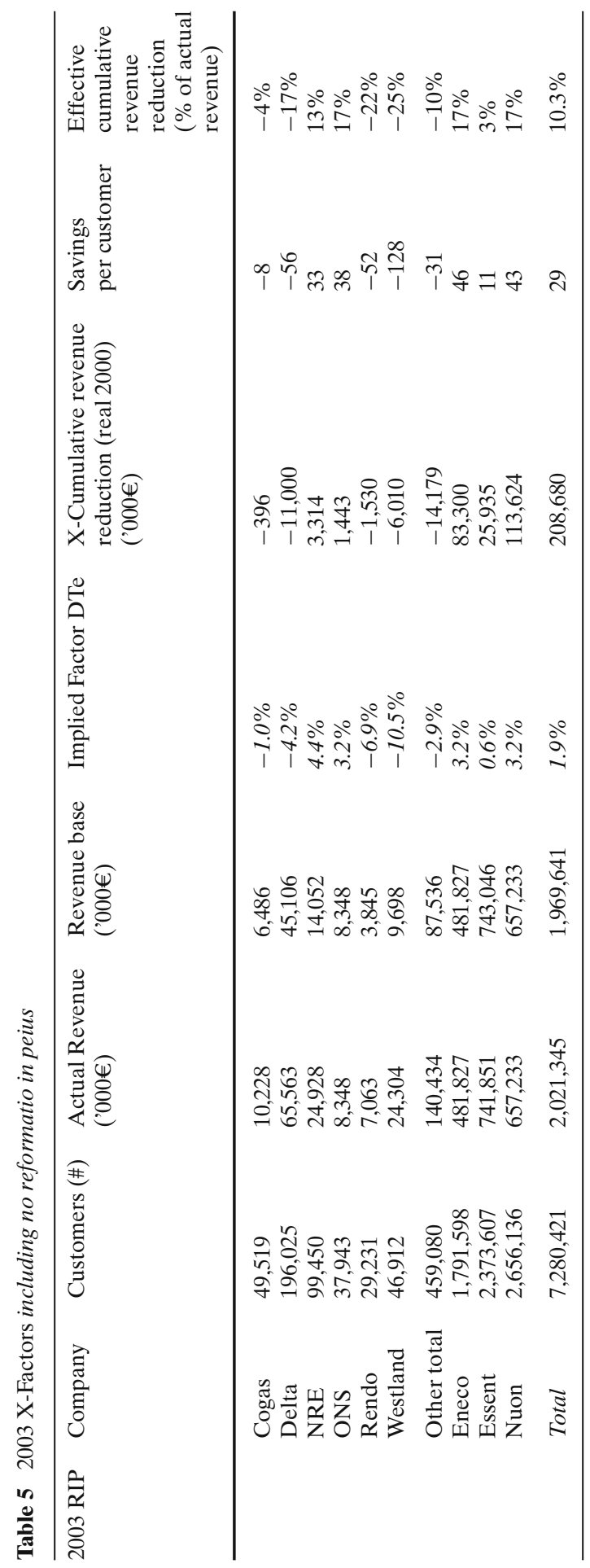


Essent. When compared with 2002, the total cost is $€ 175 \mathrm{mln}$ of which $€ 120 \mathrm{mln}$ is directly attributable to Essent. The other beneficiaries are Delta $(+€ 11 \mathrm{mln}$ instead of $-€ 11 \mathrm{mln})$ and Westland $(+€ 6 \mathrm{mln}$ instead of $-€ 4 \mathrm{mln})$.

\subsection{Summary}

The X-Factors and required revenue reductions have changed substantially during the first regulatory period. Three "stories" emerge.

The first story involves DTe getting the numbers right. This involves the period 2000-2002. The results that were presented following the clean-up session provide the most accurate picture of the relative positions and possible tariff reductions. Thus, the DTe overstated the potential cost savings in 2000 by $33 \%$. In 2000 it was suggested that customers were to see a cumulative reduction in their bills of around $€ 70$. Instead the revised figure based on actual audited data in 2002 was $€ 53$.

The second story involves DTe striking a deal following the court defeat in November 2002. The results from the new methodology used in the 2003 deal did not differ substantially from the 2002 X-Factors. The deal suggested cost savings equivalent to $17 \%$ of actual revenue (the 2002 X-factors at $19 \%$ ). Although the savings for the sector as a whole were similar, the distribution of cost reductions between companies altered substantially. The losers from this process were the shareholders of Eneco and Delta, who were required to reduce their revenues by an additional $€ 10$ and $€ 22 \mathrm{mln}$, respectively (although this was not implemented as shown later). The gainers were the shareholders of Essent and Nuon, who saw their revenue reduction decreased by $€ 19$ and $€ 54 \mathrm{mln}$, respectively.

The final story involves the dealing with past mistakes. As part of the deal DTe was required to uphold those results from 2001 that were most advantageous for the companies. This resulted in the actual tariff reductions only being $€ 209 \mathrm{mln}$ - or $10 \%$ of actual revenue. Although on paper customers stood to gain $€ 48$, the result of mistakes made in 2000/1 meant they would only receive $€ 29$. The total cost of the no reformatio in peius is $€ 140 \mathrm{mln}$ of which $€ 102 \mathrm{mln}$ is attributable to Essent (Table 6).

Table 7 shows the effect of the different stages in the revision of the X-Factors. It shows that at each "stage" DTe had to reduce the cumulative cost savings for the total sector. From $€ 70$ per customer initially, to $€ 29$ at the end of the deal including the no reformatio.

\section{The experience in context: conclusions and lessons}

The outcome of the Dutch price review process has been disappointing. In terms of the length of overrun in the process (first X-Factor set in summer of 2000, but final X-Factors agreed in May 2003) and in the unmet initial expectations it compares unfavorably to other price reviews that regularly take place in for example the UK, Norway, Australia, and Chile. Although initially promised 


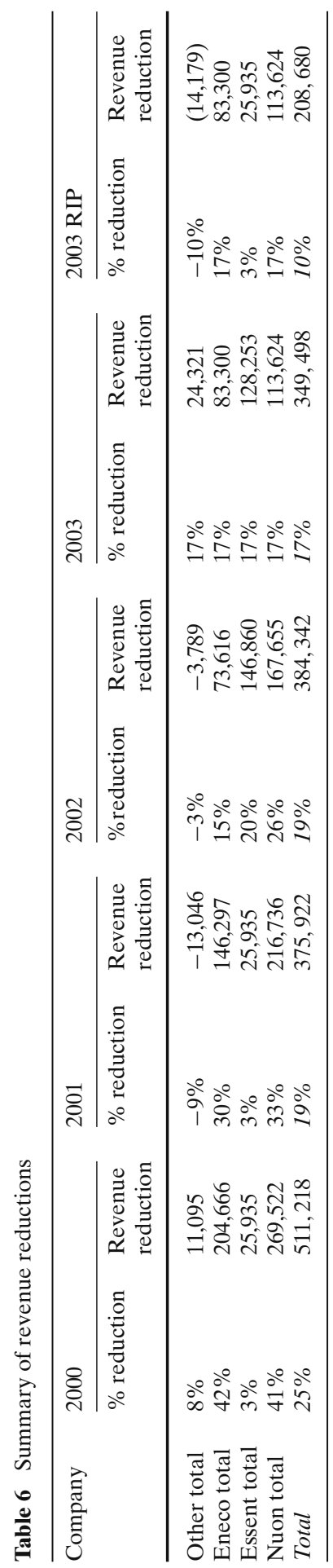


Table 7 Summary of revenue changes per customer per company

\begin{tabular}{llllll}
\hline Cumulative reduction per customer $(€)$ & Eneco & Essent & Nuon & Others & Total \\
\hline Initital estimate & 114 & 11 & 101 & 24 & 70 \\
Story 1: Initial miscalculation & -73 & 51 & -38 & -32 & -17 \\
Story 2: The deal & 5 & -8 & -20 & 61 & -5 \\
Story 3: Reformatio & 0 & -43 & 0 & -84 & -19 \\
Total effect & -68 & -0 & -59 & -55 & -42 \\
End result & 46 & 11 & 43 & -31 & 29 \\
\hline
\end{tabular}

savings of $€ 511 \mathrm{mln}$ only $€ 384 \mathrm{mln}$ of those savings turned out to be accurate. The subsequent court case defeats and previous allowance of the no reformatio in peius meant that only $€ 209 \mathrm{mln}$ of the $€ 384 \mathrm{mln}$ was achieved. The regulatory failure in The Netherlands was caused by a number of factors.

First, although the regulator and companies understood that the intention of the original Act was to set individual X-Factors, the litigation which the process gave rise to exposed the loose drafting to legal scrutiny.

Second, the timing of the process meant that during the first X-Factor setting in the summer of 2000 there was only budgeted data available for 2000-as opposed to actual audited data. DTe was forced to use data estimates to calculate legally binding X-Factors. It could however have introduced the possibility to revise X-Factors once the actual audited data became available, or as in the UK used previous year's data. The publication of preliminary results therefore gave the companies the incentive to release more accurate data. However, the legal requirement to publish a formal price control review meant that the likelihood that mistakes would influence the results was large. Together with the chosen methodology and application of the results (see point three) meant that large fluctuations in X-Factors would be possible.

Third, the mistakes that were made in the first round of X-Factors in 2000 influenced the final deal with the sector in 2003. This was partially the result of the application of the no reformatio in peius principle, which essentially allowed companies to retain favorable, though potentially erroneous X-Factors and introduced a zero-loss game for the companies. As part of the deal DTe was required to allow those network operators that should have received more favorable X-Factors to compensate for this in their tariffs. The one-sided application allowing positive benefits from mistakes to be kept (no reformatio) and negative results to be compensated has come at a substantial cost for the Dutch consumer (see the results for Essent). The total 2003 deal includes individual X-Factors for the second period that force companies back to a single "end-point" and thus compensate for these "costs". However, the mistakes from the first period have delayed overall tariff reductions for customers and the distribution of the reductions from these mistakes has not been in line with the distribution of reductions as suggested when using actual audited data (as in 2002).

In the UK, the Competition Commission looks at each case afresh and is not constrained by previous decisions of either the sector regulator or itself. 
For example, mobile phone operators have seen that the Commission does not hesitate to impose stricter price caps than suggested by the sector regulator Ofcom (Competition Commission, 2003). DTe's approach also hampers the higher appeal authority to correct potentially erroneous results that are not in the interest of consumers. The DTe's approach meant there was no risk to appealing decisions - thus encouraging companies to keep appealing as there was only an upside. DTe also only changed results for those companies involved in the appeal-although methodologically it included all the companies (e.g. Essent). DTe has indicated that in future it does not intend to apply the no reformatio principle any longer. Interestingly, the 2003 deal contains a passage that states that if-after signing the deal-DTe changes an element of the results for one party (favorably) it should do so for all other companies as well.

Rather than having a court rule on whether the law has been applied and that there has been " due process", it would be better if the appeal authority (in this case the competition authorities in The Netherlands) would have the possibility to overturn decisions. This would incentivize both the regulator and the companies to try to reach an agreement on X-Factors.

Fourth, although DTe announced the use of different benchmarking techniques to derive the X-Factors (DEA and SFA), they only used DEA and one model specification for the final determination. The results were subsequently mechanically applied to the cost structures without considering potential errors in the data that could distort the efficiency scores. The one-to-one translation using inaccurate data accentuated the X-Factors and results, as can be seen by the different outcomes between 2000 and 2002. It is difficult to separate out the different effects between 2000 and 2002 that can be attributed to data errors, model specification, and approach (e.g. determination of revenue base for benchmarking). There was no attempt to apply the results pragmatically as has been done in the UK (see Pollitt, 2005). The model specification also differed from models used elsewhere by regulators. ${ }^{30}$ A more balanced approach whereby the benchmarking results were based on several techniques would have potentially made the results more acceptable, because (a) the results are less vulnerable to the idiosyncrasies of each method giving a more balanced (less extreme) picture, (b) the weighting of the different approaches allows DTe some discretion to incorporate specific company-related factors, and (c) consistency across different models makes results more acceptable to those companies involved. Most companies are more interested in the outcome than whether a methodology is balanced. However, DTe would have had a more credible case to defend.

Finally, the Netherlands case illustrates the importance of an informed dialogue between the regulator and the companies about the progress of the regulatory review, especially when a new regulatory regime is being implemented for the first time. Once committed to the timetable the DTe failed to discuss the process sufficiently with the companies and to follow up its initial approach

$\overline{30}$ See Nillesen and Telling (2001) op. cit. 
in the July 1999 document (multiple methods, cross-checking of results, no one-to-one translation). The result was a loss of confidence in the process at an early stage by many of the companies and a litigious approach to any decision taken by DTe.

Acknowledgements The authors would like to thank the comments of Michael Crew, Liz Hooper, Jacques de Jong, David Newbery, Jan-Erik Janssen, Jan-Willem Velthuijsen, and two anonymous referees. Michael Pollitt acknowledges the financial support of CMI grant number IR-45 and the ESRC Electricity Policy Research Group. Any remaining errors are the responsibility of the authors.

The views expressed here are those of the author and do not necessarily reflect the views of PricewaterhouseCoopers N.V.

\section{References}

Armstrong, M., Cowan, S., \& Vickers, J. (1994). Regulatory reform: Economic analysis and British experience. London, Cambridge, MA: The MIT Press.

Averch, H., \& Johnson, L. L. (1962). Behavior of the firm under regulatory constraint. American Economic Review, 52, 1052-1069.

Berenschot (2003). Eindrapport Audit DTe, De Visie van Marktparijen op DTe. The Hague. 13 August 2003.

Borenstein, S., Bushnell, J., \& Wolak, F. (2002). Measuring market inefficiencies in California's restructured wholesale electricity market. American Economic Review, 92, 1376-1405.

Berg, S. (1999). Developments in best-practice regulation: Principles, processes, and performance. Florida: Public Utility Research Centre.

Better Regulation Task Force. (2003). Principles of good regulation. London: Better Regulation Task Force.

Coelli, T. (2000). Some scattered thoughts on performance measurement for regulation of a natural monopoly network industry. Centre for Efficiency and Productivity Analysis, School of Economic Studies: University of New England.

Coelli, T., Rap, D. S. P., \& Battese, G. E. (1998). An introduction to efficiency and productivity analysis. London: Kluwer Academic Publishers.

College van Beroep voor het bedrijfsleven. (2002a). NV Rendo en NV Rendo Holding tegen de Minister van Economische Zaken. No AWB 01/623. 6 February 2002. The Hague.

College van Beroep voor het bedrijfsleven. (2002b). Netbeheerders tegen de Directeur DTe. No AWB 01/841. 01/847-53. 01/955. 01/956. 13 November 2002. The Hague.

Competition Commission. (2003). Vodafone, O2, Orange and T-Mobile: Reports on references under section 13 of the Telecommunications Act 1984 on the charges made by Vodafone, O2, Orange and T-Mobile for terminating calls from fixed and mobile networks London: Competition Commission.

CPB. (2000). Yardstick competition: Theory, design, and practice, CPB Netherlands Bureau for Economic Policy Analysis. Working Paper. No. 133. December 2000. The Hague.

Crew, M. A., \& Kleindorfer, P. R. (1996). Incentive regulation in the United Kingdom and the United States: Some lessons. Journal of Regulatory Economics, 9, 211-225.

De Pree, J. K. (2002). Grenzen voor DTe. Het Financiele Dagblad. 21 February 2002.

De Telegraaf. (2002). Energiebedrijven hebben tabak van toezichthouder. 11 February 2002.

Domah, P., \& Pollitt, M. G. (2001). Restructuring and privatisation of electricity distribution and supply businesses in England and Wales: A social cost-benefit analysis. Fiscal Studies, 22/1, $107-46$.

DTe. (1999). Price cap regulation in the electricity sector, information and consultation document. July 1999. The Hague.

DTe. (2000a). Besluit, houdende vaststelling van de factor Xt, bedoeld in Artikel 41 van de Elektriciteitswet 1998. (one for each individual network operator). The Hague. 22 september 2000.

DTe. (2000b). Guidelines for price cap regulation of the dutch electricity sector. February 2000. The Hague. 
DTe. (2000c). Choice of model and availability of data for the efficiency analysis of Dutch network and supply businesses in the electricity sector. February 2000. The Hague.

DTe. (2000d). Gemiddelde efficiencykortingen elektriciteitsnetten 5.9\%. Press Release. 26 September. The Hague.

DTe. (2001). Beslissingen op de bezwaren tegen de besluiten van 22 september 2000 tot vaststelling van de $x$-factor, bedoeld in artikel 41 van de elektriciteitswet 1998 (voor alle netwerkbedrijven). 21 september 2001. The Hague.

DTe. (2002a). Correctie besluiten (eerste herziene) besluit op de bezwaren tegen de besluiten van 22 september 2000 tot vaststelling van de x-factor, bedoeld in artikel 41 van de elektriciteitswet 1998 (voor alle netwerkbedrijven). 23 augustus 2002. The Hague.

DTe. (2002b). Maatstafconcurrentie Regionale Netbedrijven Elektriciteit, Tweede Reguleringsperiode, Informatie- en Consultatie document. 20 November 2002. The Hague.

DTe. (2002c). An overview of the first regulatory review of the regional electricity networks business. July 2002. The Hague.

DTe. (2002d). Directeur De Jong stapt over naar Europees platform energietoezichthouders. Press release. 2 December 2002. The Hague.

DTe. (2002e). Gert Zijl nieuwe directeur DTe. Press release. 13 December 2002. The Hague.

DTe. (2003a). Tweede herziene besluit op bezwaar tot vaststelling van de korting ter bevordering van de doelmatige bedrijfsvoering ingevolge artikel 41, eerste lid, van de Elektriciteitswet 1998 voor de periode 2001-2003 (voor alle netbeheerders). 4 June 2003. The Hague.

DTe. (2003b). Consultatienotitie: Reparatie X-Factor Netbeheerders Elektriciteit. Visie DTe. The Hague. 16 January 2003. The Hague.

DTe. (2003c). De Overeenkomst Regulering Nettarieven Elektriciteit (2001-2006). 26 May 2003. The Hague.

Het Financiele Dagblad. (2002). Toezichthouder DTe moet luisteren. 14 February 2002.

Jamasb, T., \& Pollitt, M. (2001). Benchmarking and regulation: International electricity experience. Utilities Policy, 9/3, 107-130.

Jamasb, T., \& Pollitt, M. (2003). International benchmarking and regulation: An application to European electricity distribution utilities. Energy Policy, 31/15, 1609-1622.

Jamasb, T., Nillesen, P. H. L., \& Pollitt, M. G. (2003). Gaming the regulator: A Survey. The Electricity Journal, 16/10, 68-80.

Janssen, J. E., \& Pigmans, M. L. (2004). Tariefregulering in de Nederlandse Energiesector. In H. J. De Ru (Ed.), Monografië̈n Overheid \& Markt 3: Tarieven Regelgeving en Toezicht. The Hague: Sdu Uitgevers.

Joskow, P. (1997). Restructuring, competition and regulatory reform in the US electricity sector. Journal of Economic Perspectives, Vol 11/3. Summer 1997.

Joskow, P. J., \& Schmalensee, R. (1986). Incentive regulation for electric utilities. Yale Journal on Regulation, 4(1), 1-49.

Knops, H. P. A. (2002). X: De Grote Onbekende? NTE 2002/1.

KPMG BEA. (2000). EnergieNed: De X-Factor. September 2000.

Littlechild, S. (1983). Regulation of British telecommunications' profitability. London: Department of Industry.

Ministry of Economic Affairs. (2002). Evaluatie elektriciteitswet 1998 en gaswet. Kenmerk ME/EM/02011372. 1 March 2002. The Hague.

Ministry of Economic Affairs. (2003a). Wet van 2 juli 1998, houdende regels met betrekking tot de productie, het transport en de levering van elektriciteit (Elektriciteitswet 1998) (Stb. 2003, 235). The Hague.

Ministry of Economic Affairs. (2003b). Audit DTe, Kenmerk ME/EM3064115. 14 November 2003. The Hague.

Ministry of Economic Affairs. (2004a). Wetsvoorstel "Wijziging Elektriciteitswet 1998 en Gaswet in verband met implementatie en aanscherping toezicht netbeheer" (29 372). The Hague.

Ministry of Economic Affairs. (2004b). Vision on the Future Structure of the Energy Market. 31 March 2004. The Hague.

Ministry of Economic Affairs. (2004c). Aanpak splitsing energiebedrijven. 11 October 2004. The Hague.

Nillesen, P. H. L., \& Telling J. G. (2001). Verkeerde Signalen. Economisch Statistische Berichten. 9 February. No. 4294: 124-129. 
NYFER. (2001). Een Lekkend Prijsplafond. October 2001.

Pollitt, M. G. (1995). Ownership and performance in electric utilities. Oxford, New York: Oxford University Press.

Pollitt, M. G. (2005). The role of efficiency estimates in regulatory price reviews: Ofgem's approach to benchmarking electricity networks. Utilities Policy, 13, 279-88.

Sappington, D. E. M., Pfeifenberger, J. P., Hanser, P., \& Basheda, G. N. (2001). The state of performance-based regulation in the U.S. electric utility industry. The Electricity Journal, 14/8, 71-79.

Thanassoulis, E. (2001). Introduction to the theory and application of data envelopment analysis: A foundation text with integrate software. MA: Kluwer Academic Publishers.

The Office of Water Regulation (Western Australia). (1999). Best practice utility regulation. Utility Regulators Forum discussion paper. 